\title{
Smart Specialisation in Moderately Innovative Regions - A Qualitative Study of Poland and Lithuania
}

\author{
Svetlana Keil*
}

Smart specialisation (S3) strategies had to be prepared by the European Union (EU) member states in compliance with ex-ante conditionality to receive EU Structural and Investment Funds (ESIF). The approach of S3 has been novel and especially challenging for the regions regarded as moderate innovators 1 .

This study is a part of a larger research project and it aims to explore how novel innovation policy-making requirements affect existing policy-making traditions in such regions and how $S 3$ has been adopted in the context of the local institutional environment. Furthermore, the study seeks to explain the rationale behind the main challenges for the S3.

The cases of Poland and Lithuania are analysed using a qualitative method, based on interviews and analysis of existing documents. Structuration theory and neo-institutional theory perspectives are applied to interpret the data.

At the first sight, approaches and challenges in both countries seem alike; however, when zoomed closer, the differences emerge in terms of complexity of the processes, implementation, and evaluation of $S 3$.

Keywords: smart specialisation, entrepreneurial discovery process (EDP), innovation policy, innovation systems.

Submitted: 18.02.19 | Accepted: 10.05.19

\section{Inteligentna specjalizacja w regionach umiarkowanie innowacyjnych - badanie jakościowe Polski i Litwy}

Kraje członkowskie Unii Europejskiej (UE) musiaty przygotować strategie inteligentnej specjalizacji (S3) zgodnie z warunkowościa ex-ante, by móc korzystać z unijnych funduszy strukturalnych i inwestycyjnych (EFSI). Podejście S3 byto nowatorskie i szczególnie trudne dla regionów uznawanych za umiarkowanych innowatorów.

Niniejsze badanie jest częścia większego projektu badawczego i ma na celu zbadanie, w jaki sposób nowe wymogi dotyczace ksztattowania polityki innowacyjnej wptywaja na istniejace tradycje tworzenia polityki w tego typu regionach oraz $w$ jaki sposób przyjęto $S 3 w$ kontekście lokalnego otoczenia instytucjonalnego. Ponadto badanie ma na celu wyjaśnienie uzasadnienia głównych wyzwań zwiazanych z S3.

Przypadki Polski i Litwy sa analizowane metoda jakościowa, na podstawie wywiadów i analizy istniejacych dokumentów. Perspektywy teorii strukturacji i teorii neoinstytucjonalnej sa stosowane do interpretacji danych.

\footnotetext{
Svetlana Keil - mgr, Faculty of Management, University of Warsaw, Poland. https://orcid.org/00000002-3166-0103.

Correspondence address: University of Warsaw, 1/3 Szturmowa Street, 02-678 Warsaw, Poland.
} 
Podejście $i$ wyzwania $w$ obu krajach wydaja się początkowo podobne, jednak po gtębszej analizie pojawiaja się różnice w zakresie złożoności procesów, wdrażania i oceny S3.

Słowa kluczowe: inteligentna specjalizacja, proces przedsiębiorczego odkrywania (PPO), polityka innowacji, systemy innowacji.

Nadesłany: 18.02.19 | Zaakceptowany do druku: 10.05.19

JEL: O00, O31, O32, O33

\section{Introduction}

The approaches to innovation policy have altered over time, tending towards more inclusive and bottom-up policymaking. An example may be the smart specialisation approach (S3), which has been embraced by the EU even though the theoretical background for the concept has been deemed insufficient (Foray, 2015). As stated in one of the policy briefs: "Smart Specialisation is a place-based and experimentalist policy. Territories are encouraged to invest in learning on how to best identify, design, and implement policies that can effectively work in a specific context, rather than following universal recipes" (Gianelle, Guzzo, \& Mieszkowski, 2019, p. 1). In line with the expectations of the European Commission (EC), S3 should be designed in a bottom-up, inclusive process, while different stakeholders, such as firms, academia, and others, discover potential new activities and policy-makers facilitate the realisation of this potential (European Commission, S3 Platform, n.d. a). The process of development, implementation, monitoring, evaluation, and adjustment of S3 is known as the entrepreneurial discovery process (EDP). The S3 approach reflects place-based logic and can be seen as rooted in the innovation system approaches. The systemic approach to innovation argues that the innovation process involves an interplay between different actors, including business organisations, intermediaries, government and universities, among others (Liu, Yin, Liu, \& Dunford, 2015). This is in line with S3.

The current debate acknowledges regional differences and their impact on S3 as a place-based approach, with especially pronounced challenges for the regions regarded as moderate innovators (see:
Capello \& Kroll, 2016; Kroll, 2015). Nevertheless, evidence is lacking on how the S3 approach alters the existing institutions of innovation policy-making in the regions regarded as moderate innovators and how existing institutions affect the novel approach on the other hand. The study aims to answer this question while looking at the practices in Poland and Lithuania. The main question may be broken down into the following research questions: 1) What characterised the S3 development by the EDP in Poland and Lithuania? 2) How did the transition to the implementation phase of S3 in both countries take place? 3) What characterises the relationship of different stakeholders to the S3 development process and how did this relationship evolve? 4) What characterises the mechanisms of selecting successful applicants and assigning support for innovation in the financial period 2014-2020 in Poland and Lithuania?

This article presents the initial results of an ongoing larger research project. It is structured as follows: first, a short theoretical background will be provided, then the methodological approach will be discussed. Finally, preliminary results will be presented, followed by initial conclusions and implications for further research.

The regional innovation system perspective has been adopted as a theoretical background for S3 as a place-based approach. Results are analysed through the lenses of structuration theory, supplemented with the neo-institutional theory perspective.

\section{Theoretical Background}

\subsection{Regional Innovation System and Its Dimensions}

The regional perspective on innovation systems has got a prominent stand 
in the literature within the last decades. The definition of the region may be based upon its administrative and cultural boundaries (Cooke, Uranga, \& Etxebarria, 1998). The regional innovation systems approach appreciates the political, social and institutional context, acknowledges the embeddedness of innovation in social relations and gives credit to regional clusters and geographic proximity (Doloreux \& Parto, 2005). The existing institutional and organisational conditions may support the development of a regional innovation system, but even if these are less advantageous, the system may still evolve when the basic necessary elements are present (Cooke et al., 1998). A regional innovation system may be seen as two interdependent subsystems, one referring to knowledge application and exploitation and another one to knowledge generation and diffusion (Tödtling \& Trippl, 2011, p. 456). Scholars have captured various aspects of differences among regional innovation systems that are summarised by Tödtling and Trippl (2011, pp. 457-458): (a) capacity to develop high technology sectors, (b) governance, (c) knowledge base, (d) problems from a policy perspective. Pr nounced differences in regional innovation systems gave the background to the call for differentiated innovation policy approaches (Tödtling \& Trippl, 2005). The EC sought to embrace this call with S3. Nevertheless, Marques and Morgan (2018) argue that lacking institutional capacity may create an obstacle for S3 to bring a desired change into regions considered to be moderate innovators. The assumptions of S3 approach, such as (a) commitment of regional elites to innovation, (b) a systemic approach to innovation (as opposed to the linear model), (c) a functioning triple helix coalition, and (d) the ability to carry on multi-scalar coordination processes, may not hold in many regions (Marques \& Morgan, 2018). According to Kroll (2015), European regions have different institutional structures and unequal governance capability to implement EDP, resulting in three major groups of regions: (1) the centralist approach to planning and governance (a majority of Eastern Europe); (2) a positive institutional context, but insufficient bottom-up governance routines (usually in Southern Europe); (3) strong capabilities and supportive institutional environment to coordinate EDP (Central and Northern Europe). In the regions from the first group, EDP could not be implemented easily and the majority of time has been spent on the preparation for the exercise (Kroll, 2015). This implies that a change of governance routines and adjustments in the institutional context may be necessary for S3 to bring about desired results. Nevertheless, in his more recent work on consistency and coherence of S3 across regions, Kroll refined his findings. Differences between geography-based regional groups appeared significant for neither the consistency across the levels (strategy, priorities, and instruments) nor the coherence while translating one level into another (strategy level into priorities and these into instruments) (Kroll, 2019). The study by Kroll (2019) shows that overall administrative capacity to run EDP is the strongest predictor of both consistency and coherence measures. Trippl, Zukauskaite and Healy (2019) derive further determinants of the adoption of the S3 approach:

1) level of decentralisation/autonomy of the regional government that decides upon innovation policy and especially the distribution of funds;

2) institutional structures and quality of government in the region;

3) capabilities of regional actors to design and implement regional innovation strategies as S3;

4) past policy practices, resulting in the policy path dependency;

5) density and degree of the specialisation of industrial structure in the regional innovation system;

6) organisational thickness/thinness of the regional innovation system;

7) internal and external connectedness;

8 ) institutional structures (formal and informal), related to innovation and cooperation patterns.

\subsection{Structuration and Neo-Institutional Perspective on Organisational and Policy Change}

Institutions may be defined as "...the humanly devised constraints that structure political, economic and social interaction" (North, 1991, p. 97) or "the rules of the game" (Edquist, 2005, p. 182). Institutions may be of formal and informal nature (North, 1991). Institutions provide legitimacy for daily practices and ways of acting 
and institutional change implies a change from one prescribed pattern of practices to another (Hinings, Greenwood, Reay, \& Suddaby, 2004). In the view of Meyer and Rowan (1977), institutions take the form of rationalised myths and are mirrored within formal organisational structures, which increases the legitimacy of organisations.

Theory of structuration points to the mutual impact between the structures people are embedded in and the actions of people that alter the existing structures. Empirically, scholars distinguish between the institutional realm and the realm of action (Barley \& Tolbert, 1997; Jarzabkowski, 2008). Within the institutional realm, three types of structures may be distinguished: signification, domination, and legitimation (Giddens, 1984; Jarzabkowski, 2008). Jarzabkowski (2008, p. 623) defines the types of institutionalised structures as follows: (a) signification structures are values, beliefs, and identity that guide people's action, (b) legitimation structures are moral rules and sanctions that restrict human actions, and (c) domination structures are subdivided into resource allocative and authoritative structures. Resource allocative structures guide the allocation of material resources and the ways these may be exploited, while authoritative structures concern the authority relationships and representation of the interest of various groups in the system (Jarzabkowski, 2008). The action realm represents how individuals sustain and adapt structures of the institutional realm through the actions and interactions in their daily life (Jarzabkowski, 2008). The action realm consists of three domains: meaning, norms, and power (Jarzabkowski, 2008, p. 623). Purposive or habitual interactions convey meaning, dispense power, and elicit norms and sanctions (Giddens, 1984; Jarzabkowski, 2008). Actions may enforce existing institutions or modify them (Orlikowski, 1996). Communication, power, and sanctions refer to the realm of action, while signification, domination, and legitimation constitute the level of structures (Gray, Purdy, \& Ansari, 2015, p. 119).

DiMaggio and Powell (1983) refer to Giddens and argue that organisations become similar through the processes of homogenisation and bureaucratisation that are affected by highly structured organi- sational fields. An organisational field is defined as the totality of relevant actors and consists of suppliers, consumers, regulatory agencies, and other relevant organisations that make up a defined institutional area (DiMaggio \& Powell, 1983, p. 148). The work of DiMaggio and Powell focuses on the processes of how organisations within the fields converge towards similarity in actions. This process is known as isomorphism and its driver is pressure from the environment to resemble common practices (Meyer \& Rowan, 1977; DiMaggio \& Powell, 1983). DiMaggio and Powell distinguish three mechanisms that may drive isomorphic change: mimetic, normative and coercive. Coercive isomorphism is determined by political influence and legitimacy, mimetic isomorphism implies common reactions to uncertainty, while normative isomorphism stems from professionalisation (DiMaggio \& Powell, 1983, p. 150). Initially, studies in the field of neo-institutionalism concentrated on isomorphic processes in organisations. Later scholars examined how actors shape and transform institutions (Lawrence \& Suddaby, 2006). Suddaby and Lawrence (2006) refer to the second perspective as institutional work. Institutional work refers to the practices of either individual or collective actors that create, preserve or break institutions (Lawrence, Suddaby, \& Leca, 2011, p. 52). Lawrence and Suddaby (2006) review research on institutional work and identify what actors do to create, maintain or disrupt institutions. Forms of work aimed at creating institutions include $a d v o$ cacy, defining, vesting, constructing identities, changing normative associations, constructing normative networks, mimicry, theorising, and educating (Lawrence \& Suddaby, 2006, p. 221). Institutions are preserved through enabling work, policing, deterring, valorising and demonising, mythologising, embedding and routinising (Lawrence \& Suddaby, 2006, p. 230). Disruption of institutions may occur by disconnecting sanctions, disassociating moral foundations, and by undermining assumptions and beliefs (Lawrence \& Suddaby, 2006, p. 235).

Gray, Purdy and Ansari (2015) focus on micro-foundations of the structuring of organisational fields and emphasise the centrality of meaning to institutionalisation. They propose an interactional framing perspective as an explanation of how the 
meanings may be institutionalized. According to Gray et al. (2015), interacting actors ${ }^{2}$ do not always reproduce existing frames one-to-one, which implies that misfirings and laminations may occur. Three types of misfirings may trigger institutional change, and these include keying, frame breaks and ambiguity (Gray et al., 2015, p.119). Keying occurs when the activity remains the same but interacting actors give it another interpretation, e.g. a woman crying in court during the trial of her son may be seen as being either disruptive or emphatic (Gray et al., 2015). Thus, based on the adopted interpretation, the actions may differ. Parties may break frames purposefully if they see that given circumstances make it not reasonable to adhere to the usual interpretation of the situation, and ambiguity may emerge when different actors have different interpretations and do not try to agree on one of them (Gray et al., 2015). As a result of misfirings, powerful actors may try to restrain the new frame and reestablish the old order, but sometimes the new frame can persist and initiate change dynamics (Gray et al., 2015). Gray and others follow the terminology of Goffman ${ }^{3}$ and call the process when a new interpretation of the existing frame is added by the term lamination. Consequently, actors have multiple choice of possible interpretations, which represent different frames, rendered during the interactions at the micro-level and may be further diffused to the mesoand macro-levels or even become institutionalised (Gray et al., 2015). The process when the frames, generated at the microlevel, move towards higher levels is called amplification and it can occur in three ways: scope (adoption by a broader group), regularity (or frequency of using a specific frame) and emotional intensification (Gray et al., 2015, p. 120). The process of expanding scope occurs through networks of interactions (by growing or overlapping them); hence, structuration is a part of amplification of scope as shared meanings evolve when signification, legitimation and domination processes occur simultaneously (Gray et al., 2015). Gray and others (2015) distinguish four generic patterns of institutional change that may be very briefly summarised as follows: replacement of the existing frame, amplification of the existing frame, amplification of the modified frame, coexistence of multiple frames.

\section{Method}

Given little theoretical development of the topic of S3, a qualitative method has been chosen. The data collection is inspired by the grounded theory approach, initially developed by Glaser and Strauss in 1967 (Suddaby, 2006). Nevertheless, the approach taken in this study cannot be qualified as a grounded theory in the view of Glaser and Strauss. According to Suddaby (2006), there are two main concepts within the grounded theory: constant comparison and theoretical sampling. Constant comparison means that the process of data collection and its interpretation occur simultaneously (Suddaby, 2006, p. 634). This results in theoretical sampling, which according to Bryman and Bell (2015) is essentially an ongoing process.

Empirical data will be collected through expert interviews in Poland and Lithuania. As the current article presents preliminary results of an ongoing research project, the findings presented here are based upon eight interviews that have been conducted so far, supplemented by the data from official documents and reports relating to S3 in Poland and Lithuania. The data collection for this study follows an iterative process when thematic aspects to be covered in subsequent interviews draw upon insights from already gathered data and literature on the subject, which is consistent with the notion of constant comparison. Semi-structured and in-depth interviewing has been chosen as the main data collection method.

The sampling for the study combines a few different approaches that may be classified within a purposive sampling method, according to Bryman and Bell (2015). The sequential approach to the sampling has been taken, meaning that new participants may be added to the sample as the study evolves (Bryman \& Bell, 2015 , p. 429). Another approach guiding the sample selection is generic purposive sampling, which allows establishing criteria for the selection of the cases a priori (Bryman \& Bell, 2015). Finally, a convenience sampling element is added by using the snowball technique, where some respondents are asked to recommend further respondents for the study. The choice of the sample and sampling techniques has been made based on two reasons: (1) the 
research topic requires access to expert knowledge; therefore, interviewees should be well qualified in the field; (2) availability to approach interviewees and their readiness to devote time for interviews. Noteworthy is that such a choice of the sample techniques implies that findings cannot be generalized.

In line with the EDP, the government/ state (represented by respective organisations) has a major role as the innovation policy-maker within S3. Because of their managerial responsibility and their role as change agents, different organisations representing the state and having relevance to S3 will be given special importance, which implies a higher number of interviews conducted within this group of stakeholders, compared to other stakeholders. Table 1 provides information on conducted interviews. Interviews have been conducted in Polish and Lithuanian languages, recorded with the consent of interviewees, and transcribed.

Table 1. Summary of conducted interviews and characteristics of the sample

\begin{tabular}{|c|l|l|l|c|}
\hline \multicolumn{1}{|c|}{ Stakeholder } & \multicolumn{1}{c|}{ Type of organisation } & \multicolumn{1}{c|}{ Country } & Duration (h:min) \\
\hline 1 & Academia \& Government & University \& Ministry & Poland & $0: 58$ \\
\hline 2 & External expert & Research \& Consulting & International & $1: 31$ \\
\hline 3 & Government & Ministry & Poland & $0: 51$ \\
\hline 4 & Government & Regional authority & Poland & $0: 55$ \\
\hline 5 & Government & Agency & Lithuania & $0: 37$ \\
\hline 6 & Policy analyst & Consulting & Lithuania & $1: 11$ \\
\hline 7 & Academia & University & Lithuania & $1: 09$ \\
\hline 8 & Academia & University & Lithuania & $1: 15$ \\
\hline
\end{tabular}

Source: Own elaboration.

Approaches in Poland and Lithuania are going to be compared. The results will be discussed in line with the interpretative paradigm, which implies subjectivity of meaning and reflects how individual actors perceive the world around them (Bryman \& Bell, 2015).

\section{Brief Presentation of Innovation Policy Approach Before S3}

\subsection{Poland}

At the beginning of the financial programming perspective 2007-2013, which preceded the introduction of S3, Poland's share of business funding for $R \& D$ was declining and its share of public funding increased (ERAWATCH: Poland, 2006). Scientific specialisation lay mainly within natural and material sciences, business specialisation was mainly in the sectors of low R\&D intensity and included basic metals, mining, agriculture, and community services and the government was providing funding for the sectors with a higher value-added, such as pharmaceu- tical or machinery(ERAWATCH: Poland, 2006). Poland's business sector was mainly composed of SMEs with fewer than 250 employees; therefore, the lack of big companies could be viewed as a reason for relatively low R\&D spending by firms (Nill, 2008). In 2008, Poland was still undergoing major changes in its research system, moving towards decentralisation: from 2004 onward research priorities should be established by the Ministry of Science and Higher Education instead of the scientific community (Górzyński \& Jakubiak, 2009). Continuing the reform, funding should be provided on the project basis and move away from the statutory approach. Despite this, nearly a decade later Poland's higher education and science system was still deemed sub-optimal by experts, with underdevelopment of vocational higher education named as the main shortcoming (Marklund et al., 2017). Furthermore, experts noted that a great deal of public research facilities are located outside of universities, linkages with industry and society are rather weak (despite efforts undertaken by the government), and instruments 
used to foster science-business collaboration might be reconsidered (Marklund et al., 2017).

The role of regions in policy-making was deemed limited, although regional strategies were introduced and each region had its own operational programme and disposed of significant resources from the European Structural Funds to support innovation (Górzyński \& Jakubiak, 2009). Lacking links and low cooperation levels between business, government and higher education institutions inhibited knowledge circulation, the domestic business sector had low demand for sophisticated R\&D and knowledge (Górzyński \& Jakubiak, 2009). In 2014, low levels of business investment in R\&D and limited synergies between science and industry were still named among the main challenges for Poland's innovation system (Klincewicz, 2014). Polish National R\&D Centre established cooperation with business and other government institutions and involved technology transfer specialists for project evaluations, it also started, jointly with the industry, numerous programmes to address upcoming research trends (Klincewicz, 2014).

\subsection{Lithuania}

The level of basic research specialisation in Lithuania was among the highest compared to the EU in 2002 (ERAWATCH: Lithuania, 2006). Scientific specialisation lay in the fields of natural sciences, mathematics, and computer sciences, technological specialisation in 2001-2003 was limited to electronic equipment and office machinery, and economic specialisation concentrated on telecommunication and transportation activities (ERAWATCH: Lithuania, 2006). Asymmetric concentration of R\&D resources and weak inter-sectoral links prevailed, while at the same time public spending on R\&D was increasing, with EU funding partially replacing national expenditures (Kriaucioniene, 2009). The strength of the research system at that time lay in the high number of graduates in the fields of science and technology, but this effect was diminished by the insufficient quality of the public higher education sector and lacking opportunities for careers (Kriaucioniene, 2009).

In terms of innovation-related policymaking, two ministries share responsibility: the Ministry of Economy being responsible for innovation policy, while the Ministry of Education and Science coordinates education and public R\&D policy, which results in competition and lacking trust between these bodies (Paliokaite, 2015). Additionally, the Ministry of Finance is responsible for managing ESIF funds (Paliokaite, 2015). According to Respondent 5, Lithuania has been setting research and innovation priorities, but these have been different documents, first with the S3 approach it is clear that now it has to be one single document. Lithuania's innovation system was deemed fragmented (OECD, 2016; Paliokaitè, 2017; Paliokaitè, Petraitè, \& Gonzalez Verdesoto, 2018).

\section{Preliminary Results}

Due to an akin social and economical context, a similar approach and challenges characterised S3 development by EDP in both countries, nevertheless, some differences are notable:

1) In Poland, $S 3$ has been designed at two levels, national and regional, with diverse approaches. This resulted in lacking coordination between national and regional S3 and at the moment there seem to be two S3: one regional and one national (Otręba-Szklarczyk et al., 2017, p. 13).

2) Foresight exercises have been run in both cases, but in Poland foresight exercises took place before S3 development, while in Lithuania they were run for S3 development. In Lithuania, policy-makers with the help of external consultants designed guidelines for the process and conducted initial analyses. This served as the background for selecting fields for detailed priorities to be defined. From this point, the EDP reaches more actors as working groups for every priority field are designed. In Poland, at the national level, the main sources of evidence that lead to the emergence of priority fields are two foresight reports: technology foresight InSight 2030 and Polska 2020: the first one is about technology and business, while the second one identifies societal challenges the country is facing (Otręba-Szklarczyk et al., 2017). Similarly to Lithuania, working groups have been designed to discuss priorities for every priority field. 
3) Both countries struggled with the involvement of business in the process (Respondent 5, Respondent 6; Respondent 3; Otręba-Szklarczyk et al., 2017).

4) At the national level, both countries developed broad lists of priorities: six fields and 20 priorities in Lithuania and five fields and 20 priorities in Poland. As noted by Gianelle, Guzzo and Mieszkowski (2019), nested priorities, representing a tree-like structure where bigger fields branch into more detailed priorities, were a common approach in different regions across the EU. Nevertheless, the final number of defined priorities is especially interesting given the size of both countries: according to Eurostat, Poland is about 13 times as populous as Lithuania (Eurostat, n.d.).

To assess changes in the innovation policy with the introduction of S3, the transition to the implementation phase of S3 will be contrasted with the previous financial programming perspective. In the finan- cial programming perspective 2007-2013, Lithuania aimed to speed up economic growth and close the gap to the EU average (European Commission, Regional Policy, n.d.). To achieve this goal, operational programme (OP) Economic Growth was designed to allocate the funding and it concentrated on the objectives listed in the first column of Table 2. For the programming period 2014-2020, in Lithuania there is a single OP for the entire ESIF to be invested, with dedicated amounts of funding for each of the EU specific thematic objectives (TO), where TO Research and Innovation is assigned 10.12\% (European Commission, Regional Policy, n.d.). Additionally, some instruments confirmed under TO Education and Vocational Training may be relevant as these aim to strengthen the potential of the public research system and provide better qualified human resources (Visionary Analytics, 2017a). Specific objectives for the Lithuanian RDI policy, relevant for S3, are listed in the second column of Table 2.

Table 2. Comparison of ESIF investment objectives in Lithuania during financial programming perspectives 2007-2013 and 2014-2020

\begin{tabular}{|c|c|}
\hline 2007-2013 & 2014-2020 \\
\hline $\begin{array}{l}\text { - Increase the share of high value-added } \\
\text { businesses; } \\
\text { - boost productivity, particularly by creating } \\
\text { favourable conditions for innovation and } \\
\text { small and medium enterprises (SMEs); } \\
\text { - improve the efficiency of economic } \\
\text { infrastructure. }\end{array}$ & $\begin{array}{l}\text { - Promoting the use of existing and new RDI } \\
\text { infrastructure; } \\
\text { - Enhancing the intensiveness } \\
\text { of RDI activities in the private sector; } \\
\text { - Enhancing knowledge commercialisation } \\
\text { and technology transfer; } \\
\text { - Strengthening skills and capacities } \\
\text { of the public research sector. }\end{array}$ \\
\hline
\end{tabular}

Source: Own compilation from European Commission, Regional Policy, n.d. (first column); Visionary Analytics, 2017b, p. 2 (second column).

In Poland, during the financial programming perspective 2007-2013 more attention was given to the strengthening of science and research potential, while during the 2014-2020 period there is a shift towards the enterprise sector. This becomes evi- dent when comparing the priority axes of the main operational programmes through which ESIF is allocated. These are OP Innovative Economy (POIG) in 2007-2013 and OP Innovative Growth (POIR) in 2014-2020, compared in Table 3. 
Table 3. Comparison of ESIF investment objectives in Poland during financial programming perspectives 2007-2013 and 2014-2020

\begin{tabular}{|c|c|}
\hline $2007-2013$ & 2014-2020 \\
\hline $\begin{array}{l}\text { - Improving enterprise innovativeness; } \\
\text { - Improving the scientific community's } \\
\text { competitiveness in Poland; } \\
\text { - Strengthening economic development } \\
\text { through good science; } \\
\text { - Increasing the international market share } \\
\text { of innovative products made in Poland; } \\
\text { - Creating permanent and better places } \\
\text { to work; } \\
\text { - Boosting ICT usage in Poland's economy. }\end{array}$ & $\begin{array}{l}\text { - Increasing the number and the quality } \\
\text { of research and development projects } \\
\text { carried out by enterprises; } \\
\text { - Improving the institutional conditions } \\
\text { enabling enterprises to engage in R\&D } \\
\text { activities and enhancing their potential } \\
\text { for R\&D; } \\
\text { - Supporting innovation in enterprises, in } \\
\text { particular by providing financial instruments } \\
\text { for innovative investments and assisting } \\
\text { innovative exporting companies from key } \\
\text { sectors in further internationalisation; } \\
\text { - Enhancing the links between public } \\
\text { research, business and the needs of } \\
\text { the economy by investing in strategic } \\
\text { public R\&D infrastructure and research } \\
\text { programmes with the highest potential for } \\
\text { the Polish economy. }\end{array}$ \\
\hline
\end{tabular}

Source: Own compilation from European Commission, Regional Policy, n.d.

Notably, POIR combines TO Research and Innovation with TO Competitiveness of SMEs (European Commission, Regional Policy, n.d.). This may allow for additional synergies (Visionary Analytics, 2017a).

Tables 4 and 5 depict how the relationship of different stakeholders to S3 evolved, concerning various aspects.

Concerning the mechanisms of selecting successful applicants and assigning support for innovation in the financial programming period 2014-2020 in Poland and Lithuania, experts play a major role during the project selection phase. POIR has the largest number of experts at its disposition, compared to other OPs, and experts make up $73 \%$ of the Project Evaluation Committee (Ministerstwo Inwestycji i Rozwoju, 2019, p.16). Interestingly, for POIR, in $59 \%$ of cases, the value of the finished call concerning the submitted applications was lower than the funds dedicated for the call (Ministerstwo Inwestycji i Rozwoju, 2019, p. 13). This implies low absorption capacity by the potential beneficiaries. Accord- ingly, selected beneficiaries absorbed on average $47 \%$ of allocated funding per call and, on average, $34 \%$ of applications were selected for financing (Ministerstwo Inwestycji i Rozwoju, 2019, pp. 21-22).

According to the scheme on the website dedicated to EU funds in Lithuania, implementing institutions issue calls and applicants can apply via specially designed data exchange website (DMS) (Esinvesticijos.lt, n.d.). Similar to Poland, employees of the implementing institution and experts evaluate the projects. As evident from the aforementioned scheme, in Lithuania, two aspects have to be considered: a) eligibility for the financing in terms of general and special project criteria, b) usefulness and quality of the project, based on the priority criteria (where the application can collect up to 100 points and is rejected if it does not reach the minimum of points). The final decision upon the financing of selected projects lies within the ministry in charge (Esinvesticijos.lt, n.d.). 


\begin{tabular}{|c|c|}
\hline Stakeholder & Lithuania \\
\hline Government & $\begin{array}{l}\text { - S3 seen sceptically due to previous negative experiences with prioritisation } \\
\text { efforts. With the accession to the EU, different ministries attempted to set } \\
\text { RDI priorities for different sectors, which was perceived as lobbying and } \\
\text { brought fragmentation and increase of priorities across fields (Paliokaite et } \\
\text { al., 2015). } \\
\text { - No previous experience with regional innovation strategies (Respondent 6). } \\
\text { - Some policy-makers involved in the process as coordinators and } \\
\text { facilitators (e.g. MOSTA), others take the role of an observer. As noted by } \\
\text { Respondent 8, representatives of the policy-makers take part in meetings } \\
\text { but cannot contribute much to the initial stages due to a lack of specific } \\
\text { knowledge in respective fields. During the last meeting, when it comes to } \\
\text { implementation and necessary support, government representatives take } \\
\text { initiative (Respondent 6; Respondent 8). } \\
\text { - External organisations, contracted in the public procurement procedure, } \\
\text { involved in methodological support and facilitation (Paliokaite, Martinaitis, } \\
\text { \& Reimeris, 2015). } \\
\text { - Action plans for every priority field (ŠMM, n.d.). } \\
\text { - A different interpretation of state aid rules than in Poland hampers flexibility } \\
\text { in designing support (Visionary Analytics, 2017a). } \\
\text { - There are 20 financial instruments available (Visionary Analytics, 2017a). } \\
\text { The mix of instruments is modified during the S3 implementation phase } \\
\text { (Dunauskas et al., 2018). } \\
\text { - Experts presented suggestions for revision to the government (MOSTA, n.d.). } \\
\text { - Monitoring has been delegated to the Ministry of Economics and Innovation } \\
\text { and MOSTA (Dunauskas et al., 2018). }\end{array}$ \\
\hline Business & $\begin{array}{l}\text { - Scepticism, lacking trust (Respondent 5; Respondent } 6 \text { ). } \\
\text { - The government had to manage the tension between the need to include } \\
\text { business into the prioritisation process and being accused of lobby influences } \\
\text { due to negative attitudes in the society towards business (Respondent } 6 \text { ). } \\
\text { - Involvement in the development of the roadmaps for implementation via } \\
\text { working groups (evident from the lists of participants in the working groups' } \\
\text { meetings). } \\
\text { - Different application success rate within different priorities (Dunauskas, } \\
\text { Jaujininkas, Lapienis, Reimeris, \& Valatka, 2017; Paliokaite, Petraite, \& } \\
\text { Gonzalez Verdesoto, 2018). }\end{array}$ \\
\hline Academia & $\begin{array}{l}\text { - Scientists followed discussion at the EU level (Respondent 7; Respondent 8). } \\
\text { - Government invited scientists to participate in the EDP, as official EU } \\
\text { documents with ex-ante condition appeared (Respondent 7; Respondent 8). } \\
\text { - Involvement in the development of the roadmaps for implementation via } \\
\text { working groups (evident from the lists of participants in the working groups' } \\
\text { meetings). } \\
\text { - Participation in collaborative projects difficult due to the co-financing } \\
\text { requirement (Respondent 8). } \\
\text { - Involvement as experts in working groups to suggest amendments to S3 } \\
\text { (Respondent 8). }\end{array}$ \\
\hline
\end{tabular}

Source: Own elaboration. 


\begin{tabular}{|c|c|}
\hline Stakeholder & Poland \\
\hline Government & $\begin{array}{l}\text { - Sectoral programmes are seen as initiatives, similar to EDP (Mieszkowski } \\
\text { \& Kardas, 2015). However, as noted by Respondent 2, it could be difficult to } \\
\text { aggregate about } 30 \text { programmes into a more limited number of priorities. } \\
\text { - Some experience with the regional innovation system approach at the } \\
\text { regional level (but not at the national). As noted by one of the regional } \\
\text { representatives: the previous approach has still been too fresh to establish well- } \\
\text { functioning innovation systems in the regions (Respondent 4). } \\
\text { - At the national level, the main sources of evidence are two foresight reports, } \\
\text { completed before the introduction of S3 (Otręba-Szklarczyk et al., 2017). At } \\
\text { the regional level, external experts have also been involved (Respondent 2). } \\
\text { - Approaches in different regions varied in their quality (World Bank, n.d.). } \\
\text { - Implementation through OP Smart Growth (POIR) at the national level } \\
\text { and } 16 \text { regional OPs. POIR distinguishes 14 financial instruments across four } \\
\text { priority axes, but these may be further subdivided into different variations, which } \\
\text { results in a high variety of available support (Visionary Analytics, 2017a). } \\
\text { - The document has been regularly updated, the number of specialisations } \\
\text { reduced (updated documents are published on the Polish website dedicated } \\
\text { to S3: smart.gov.pl). } \\
\text { - The country still lacked a well-established monitoring mechanism: the } \\
\text { monitoring body was composed of working groups, economic observatory, } \\
\text { steering committee and consultative group (Klincewicz, Marczewska, } \\
\text { \& Szkuta, 2018). }\end{array}$ \\
\hline Business & $\begin{array}{l}\text { - } \text { Business landscape is perceived as scarce (Otręba-Szklarczyk et al., 2017). } \\
\text { - The rate of business respondents in the InSight } 2030 \text { varied between 4\% } \\
\text { in the first and 6\% in the second round (Polish Chamber of Commerce } \\
\text { for High Technology, 2011). } \\
\text { - The pilot project of the World Bank was run in five regions }{ }^{4} \text { and involved } \\
\text { SMEs, aiming to establish the EDP model, which proposes the use of } \\
\text { interviews, "smart lab" workshops, innovation maps and crowdsourcing } \\
\text { platform as building blocks for EDP (World Bank Group, n.d., pp. 20-30). } \\
\text { - Possibility to be involved in the design of POIR and financial instruments } \\
\text { mainly via socio-economic partners and association of entrepreneurship } \\
\text { (Respondent 3). } \\
\text { - Different application success rate within different priorities as confirmed } \\
\text { by Respondent } 3 \text { and evident from the latest data available on the } \\
\text { implementation of S3 priorities in Poland for June 2016 (MR, 2016). } \\
\text { - Involvement of business in the EDP may bear risks that have not been } \\
\text { appreciated yet, these risks relate to the lack of trust between different } \\
\text { entrepreneurs as well as between entrepreneurs and public administration } \\
\text { (Otręba-Szklarczyk et al., 2017). }\end{array}$ \\
\hline Academia & $\begin{array}{l}\text { - Scientists were involved in the discussion at the very early stages when S3 was still } \\
\text { an academic topic, which spread into the broader community after EU official } \\
\text { documents appeared (Respondent 1). } \\
\text { - During the Delphi exercise within InSight 2030, scientists constituted } 84 \% \\
\text { and } 85 \% \text { of respondents in the first and second round respectively (Polish } \\
\text { Chamber of Commerce for High Technology, 2011). } \\
\text { - Support for academia is available within the fourth priority axis of POIR, } \\
\text { via participation in joint consortia with business or other universities } \\
\text { or research units (POIR, p. 112). } \\
\text { - Involvement as partners in the monitoring and evaluation process, notably } \\
\text { in some regions, e.g. in Silesia via Network of Regional Specialised } \\
\text { Observatories within EDP5. }\end{array}$ \\
\hline
\end{tabular}

Source: Own elaboration. 


\section{Conclusion and Implications for Further Research}

Initial results show similar struggles with S3 in Poland and Lithuania. Both countries ended up with rather broad lists of priorities, which is mainly due to the time pressure to deliver the official documents of S3 (Paliokaite, 2015). But also due to the anxiety about not being able to absorb funds if the fields are too focused as the innovative business landscape is rather scarce (Otręba-Szklarczyk et al., 2017). The bottom-up approach may require time for discussion and leveraging interests of different stakeholders and actors within particular groups for priorities to emerge. This might to some extent be fixed as a result of mid-term revisions taking place in both countries. Concerning the research questions, stated at the beginning of this article, preliminary answers may be as follows:

- EDP, as intended by S3, is still evolving both in Poland and in Lithuania. The mechanisms ensuring possibilities for a broader range of stakeholders' participation could not be recognized yet, based on the current research material. Concerning the factors discussed in this article, setting up these mechanisms may be hindered by the fragmentation of the innovation system, the low institutional capacity of policy-making bodies and lacking trust. To express this in terms of the neo-institutional and the structuration theory, lacking links and fragmentation may hinder the amplification of the new frame (Gray, Purdy, \& Ansari, 2015). Therefore, there is a risk that no change will happen or multiple frames may co-exist.

- Concerning the second research question, implementation in Lithuania started with a substantial delay, which is mainly attributed to the late start of the financial instruments (Respondent 5; Dunauskas et al., 2017). In Poland, the monitoring system had still to be developed (Respondent 3; Respondent 4). This indicates that initially EDP in these countries was mainly focused on defining priorities, with other aspects receiving less attention.

- The relationship of different stakeholders to S3 may be determined by the fragmentation of the innovation system and a lack of triple or quadruple helix coalition (identified as a heroic assumption by Marques and Morgan (2018)). Therefore, there could be a potential mismatch between the groups defining priorities, financial instruments, and the ones who could be potentially innovating. In Poland, science could reap fewer benefits, compared to the previous financial programming perspective, because the focus within S3 should be shifted towards innovating firms. In Lithuania, scientist might have difficulties to join the projects due to the co-financing requirement (as noted by Respondent 8). Business in both countries has been rather sceptical.

- Due to the specific nature of the projects within S3, their selection mechanisms rely heavily upon expert evaluation.

Summarising, the conclusion may be that policy-makers started seeking advice from local experts and representatives of the science and business communities, which formerly was not always the case, especially regarding business participation in innovation policy-making. Further research could examine how this may influence policy decisions, considering different aspects. The relative low application success rate in some priority fields, especially where business interest is potentially high, might point to the problems of understanding by business the support scheme or the nature of the projects that could be eligible for the funding. Alternatively, it could indicate an inadequacy of project evaluation criteria or mismatch between chosen priorities and activities of firms. This could be another subject for further research. Even though while selecting priorities for S3, societal challenges were considered, the society played a passive role in defining S3 both in Poland and in Lithuania. Moreover, its involvement has not been considered seriously, which can be so interpreted based on official documents that have no mentions about society involvement measures. The implications of vague society engagement within S3 could also constitute a research topic.

\section{Endnotes}

1 In this study, moderately innovative regions are defined in line with the definition of Innovation Union Scoreboard, meaning that the innovative 
performance of the region is below $90 \%$ of the EU average. This also includes modest innovators, whose performance lies below $50 \%$ of the EU average.

2 Gray et al. (2015) use the term "interactant" when they refer to interacting actors. In this article, this will be referred to as interacting actors to keep consistent terminology through literature sources talking about similar phenomena.

3 An outline of interactional framing is given by Goffman in his work Frame analysis: An essay on the organization of experience, which first appeared in 1974.

4 Dolnośląskie, Zachodniopomorskie, Świętokrzyskie, Sląskie.

5 For more information see https://ris.slaskie. pl/czytaj/siec_regionalnych_obserwatoriow_ specjalistycznych_w_ppo_2017_2019.

\section{References}

Barley, S.R., \& Tolbert, P.S. (1997). Institutionalization and structuration: Studying the links between action and institution. Organization Studies, 18(1), 93-117.

Bryman, A., \& Bell, E. (2015). Business research methods. USA: Oxford University Press.

Capello, R., \& Kroll, H. (2016). From theory to practice in smart specialization strategy: Emerging limits and possible future trajectories. European Planning Studies, 24(8), 1393-1406.

Cooke, P., Uranga, M.G., \& Etxebarria, G. (1998). Regional systems of innovation: An evolutionary perspective. Environment and Planning A, 30(9), 1563-1584.

DiMaggio, P.J., \& Powell, W.W. (1983). The iron cage revisited: Institutional isomorphism and collective rationality in organizational fields. American Sociological Review, 48(2), 147-160.

Doloreux, D., \& Parto, S. (2005). Regional innovation systems: Current discourse and unresolved issues. Technology in Society, 27(2), 133-153.

Dunauskas, S., Jaujininkas, V., Lapienis, J., Reimeris, R., \& Valatka, V. (2017). Sumanios specializacijos pažanga. Pirmoji ataskaita. Vilnius.

Dunauskas, S., Izgorodin, A., Jakubavičius, A., Kamaitis, P., Penelytė, I., Rakštytė-Hoimian, J., \& Žemaitytè, R. (2018). Sumanios specializacijos igyvendinimo pažangos vertinimas. LIETUVOS RESPUBLIKOS ÜKIO MINISTERIJA, VŠI MOKSLO IR STUDIJŲ STEBĖSENOS IR ANALIZĖS CENTRAS. Retrieved from https:// strata.gov.lt/images/tyrimai/sumanios-specializacijos-pazangos-vertinimas.pdf.

European Commission (S3 Platform). (n.d.). Joint Research Centre, Institute for Prospective Tech- nological Studies. Retrieved on 2 December 2019 from http://s3platform.jrc.ec.europa.eu/entrepreneurial-discovery-edp.

European Commission (Regional Policy). (n.d.). EU Regional and Urban Development, Regional Policy. Retrieved on 25 January 2019 from https:// ec.europa.eu/regional_policy/en/atlas/programmes/.

Edquist, C. (2005). Systems of innovation: Perspectives and challenges. In The Oxford handbook of innovation. Oxford University Press.

ERAWATCH Network. (2006). ERAWATCH country specialisation report. Country: Lithuania.

ERAWATCH Network. (2006). ERAWATCH country specialisation report. Country: Poland.

Esinvesticijos.lt: 2014-2020 EU Investment in Lithuania. Retrieved on 25 January 2019 from from https://esinvesticijos.lt/lt//finansavimas/finansavimoskyrimo-schema.

Eurostat. (n.d.). Retrieved on 25 January 2019 from https://ec.europa.eu/eurostat/data/statistics-a-z/abc.

Foray, D. (2015). Smart specialisation. Opportunities and challenges for regional innovation policy. London and New York: Routledge.

Gianelle, C., Guzzo, F., \& Mieszkowski, K. (2019, May). Smart specialisation from concept to practice. Smart specialisation - JRC policy insights, JRC116297.

Giddens, A. (1984). The constitution of society. Outline of the theory of structuration. Berkley and Los Angeles: University of California Press.

Górzyński, M., \& Jakubiak, M. (2009). ERAWATCH country report 2008. An assessment of research system and policies. Poland.

Gray, B., Purdy, J.M., \& Ansari, S. (2015). From interactions to institutions: Microprocesses of framing and mechanisms for the structuring of institutional fields. Academy of Management Review, 40(1), 115-143.

Hinings, C.R., Greenwood, R., Reay, T., \& Suddaby, R. (2004). The dynamics of change in organizational fields. In M.S. Poole \& A.H. Van de Ven, Handbook of organizational change and innovation. Oxford, UK: Oxford University Press.

Jarzabkowski, P. (2008). Shaping strategy as a structuration process. Academy of Management Journal, 51(4), 621-650.

Kriaucioniene, M. (2009). ERAWATCH country report 2008. An assessment of research system and policies. Lithuania.

Klincewicz, K. (2014). ERAWATCH country reports 2013: Poland. Luxembourg: Publications Office of the European Union.

Klincewicz, K., Marczewska, M., \& Szkuta, K. (2018). RIO country report 2017: Poland. Research and Innovation Observatory country report series. 
Luxembourg: Publications Office of the European Union.

Kroll, H. (2015). Efforts to implement smart specialization in Practice-Leading unlike horses to the water. European Planning Studies, 23(10), 2079-2098.

Kroll, H. (2019). Eye to eye with the innovation paradox: Why smart specialization is no simple solution to policy design. European Planning Studies, 27(5), 932-951.

Lawrence, T.B., \& Suddaby, R. (2006). Institutions and institutional work. In The SAGE handbook of organization studies (pp. 215-254).

Lawrence, T., Suddaby, R., \& Leca, B. (2011). Institutional work: Refocusing institutional studies of organization. Journal of Management Inquiry, 20(1), 52-58.

Liu, Z., Yin, Y., Liu, W., \& Dunford, M. (2015). Visualizing the intellectual structure and evolution of innovation systems research: A bibliometric analysis. Scientometrics, 103(1), 135-158.

Marklund, G., Naczinsky, C., Ziarko, W., Winckler, G., Puukka, J., File, J.M., ... \& Melin, G. (2017). Peer review: Poland's higher education and science system: Horizon 2020 policy support facility.

Marques, P., \& Morgan, K. (2018). The heroic assumptions of smart specialisation: A sympathetic critique of regional innovation policy. In New avenues for regional innovation systems - theoretical advances, empirical cases and policy lessons (pp. 275-293).

Meyer, J.W., \& Rowan, B. (1977). Institutionalized organizations: Formal structure as myth and ceremony. American Journal of Sociology, 83(2), 340-363.

Mieszkowski, K., \& Kardas, M. (2015). Facilitating an entrepreneurial discovery process for smart specialisation. The case of Poland. Journal of the Knowledge Economy, 6(2), 357-384. doi:10.1007/ s13132-015-0242-y.

Ministerstwo Rozwoju (MR). (2016). Krajowa inteligentna specjalizacja. Retrieved on 2 December 2018 from http://www.smart.gov.pl/pl/monitorowani wyniki.

Ministerstwo Inwestycji i Rozwoju, Departament Koordynacji Wdrażania Funduszy Unii Europejskiej. (2019). Wybór projektów w ramach krajowych i regionalnych programów na lata 2014-2020 (stan na 30 czerwca 2019 roku). Warszawa.

Mokslo ir studijų stebėsenos ir analizès centras (MOSTA): sumani2020.1t Retrieved on 2 December 2018 from http://sumani2020.lt/naujienos/98ekspertai-ivertino-sumanios-specializacijoskrypciu-perspektyvas.

Nill, J. (2008). ERAWATCH analytical country report 2007: Poland.
North, D.C. (1991). Institutions. The Journal of Economic Perspectives, 5(1), 97-112.

OECD. (2016). OECD reviews of innovation policy: Lithuania 2016. Paris: OECD Publishing.

Orlikowski, W. J. (1996). Improvising organizational transformation over time: A situated change perspective. Information Systems Research, (7)1, 63-92.

Otręba-Szklarczyk, A., Pierzchała, M., Strzebońska, A., Szklarczyk, D., Ulatowska, R., Winogrodzka, D., \& Worek, B. (2017). Ewaluacja ex-ante projektu pozakonkursowego „Monitoring krajowej inteligentnej specjalizacji” Programu Operacyjnego Inteligentny Rozwój 2014-2020: raport końcowy z badania ewaluacyjnego. Warszawa-Kraków.

Paliokaitè, A. (2015). Stairway to excellence country report: Lithuania. European Commission, Joint Research Centre, Institute for Prospective Technological Studies.

Paliokaite, A. (2017). Specific support for Lithuania - Background report. Horizon 2020 policy support facility. Luxembourg: Publications Office of the European Union.

Paliokaite, A., Martinaitis, Ž., \& Reimeris, R. (2015). Foresight methods for smart specialisation strategy development in Lithuania. Technological Forecasting and Social Change, 101, 185-199.

Paliokaitè, A., Petraitė, M., \& Gonzalez Verdesoto, E. (2018). RIO country report 2017: Lithuania. Research and Innovation Observatory country report series. Luxembourg: Publications Office of the European Union.

Polish Chamber of Commerce for High Technology. (2011). Foresight Technologiczny Przemystu InSight 2030. Tom III - Badanie Delphy i konsultacje spoteczne. Retrieved on 7 December 2018 from http://iztech.pl/studiaanalizy/366-foresight-terchnologiczny-przemysu-insight-2030.

Program Operacyjny Inteligentny Rozwój na lata 2014-2020 (POIR). Retrieved on 24 January 2019 from https://www.poir.gov.pl/.

Suddaby, R. (2006). From the editors: What grounded theory is not. Academy of Management Journal, 49(4), 633-642.

Švietimo, Mokslo ir Sporto Ministerija (ŠMM). Sumani specializacija Retrieved on 24 January 2019 from https://www.smm.lt/web/lt/mokslas/ sumani_spec.

Tödtling, F., \& Trippl, M. (2005). One size fits all?: Towards a differentiated regional innovation policy approach. Research Policy, 34(8), 1203-1219.

Tödtling, F., \& Trippl, M. (2011). 33 Regional innovation systems. In Handbook of regional innovation and growth (pp. 455-465).

Trippl, M., Zukauskaite, E., \& Healy, A. (2019). Shaping smart specialization: The role of place- 
specific factors in advanced, intermediate and less-developed European regions. Regional Studies, 1-13. https://doi.org/10.1080/00343404.2019.15 82763.

Visionary Analytics. (2017a). Veiksmu programos uždaviniu, skirtu moksliniams tyrimams, eksperimentinei pletrai ir inovacijoms skatinti, igyvendinimo pažangos vertinimo paslaugos: Galutine vertinimo ataskaita. Vilnius.
Visionary Analytics. (2017b). Evaluation of progress in implementing the objectives of the operational programme designed for promotion of research and development and innovations: Summary of the final report. Vilnius.

World Bank Group. Toward an innovative Poland: The entrepreneurial discovery process and business needs analysis. Retrieved on 24 January 2018 from http://documents.worldbank.org. 